\title{
The domestic, the wild and its interstices: what can a dog do in Tierra del Fuego
}

\author{
Luisa Amador Fanaro' \\ 'Universidade Federal de São Carlos, Programa de Pós-Graduação em Antropologia Social, \\ São Carlos/SP, Brasil
}

\begin{abstract}
This study examines dogs that pull sledges in tourist activities in Ushuaia (capital of Tierra del Fuego province) and their relations with their breeders (the mushers) and with the tourists they both work for. Nevertheless, during my field research I also came across other dogs in other contexts, among them the numerous companion dogs abandoned in the city and the so-called "wild dogs", who live in rural areas and are thus seen by Fuegians as "harmful animals" and an "invasive alien species" - that is, a problem to be solved. In this paper I consider sled dogs and wild dogs, and the different statuses that dogs can assume in these different contexts in which animals and humans relate, considering that in Tierra del Fuego canine work operates as a domesticity regime.
\end{abstract} Key words: human-animal relations; animal work; sled dogs; feral dogs; domesticity.

\section{O doméstico, o selvagem e seus interstícios: o que pode um cão na Terra do Fogo}

\section{Resumo}

O tema deste trabalho são os cães que puxam trenós na atividade turística em Ushuaia (capital da Província da Terra do Fogo/Argentina) e suas relações com seus criadores (os mushers) e com os turistas, para os quais ambos trabalham. No entanto, durante minha permanência em campo deparei-me também com outros cães em outros contextos, dentre eles os inúmeros cães de companhia abandonados na cidade e os "cães selvagens", que habitam as zonas rurais e constituem, para os fueguinos, "animais daninhos" e "espécie exótica invasora" - ou seja, um problema a ser resolvido. Destarte, neste artigo proponho-me a pensar, com atenção especial aos cães de trenó e aos cães selvagens, quais são os diferentes estatutos que os cães podem vir a assumir nesses contextos diversos em que animais e humanos se relacionam, tendo em conta que, na Terra do Fogo, o trabalho canino opera como um regime de domesticidade.

Palavras-chave: relações humano-animal; trabalho animal; cães de trenó; cães ferais; domesticidade. 


\title{
The domestic, the wild and its interstices: what can a dog do in Tierra del Fuego
}

\author{
Luisa Amador Fanaro
}

\section{From work to ostracism, dogs in Tierra del Fuego}

This paper presents a multispecific ethnography with dogs that pull sleds for tourist activities in Ushuaia, the capital of Tierra del Fuego province in Argentina, based on research completed in 2019. ${ }^{.}$The discussions focus on the relationships of these animals with their breeders (who are also sled drivers) and with tourists, for whom both work ${ }^{2}$. Nevertheless, during my first weeks in the field, in addition to sled dogs, I unexpectedly encountered a myriad of other dogs, including companion dogs abandoned on city streets and so-called wild dogs $s^{3}$, which constitute, according to farmers and much of the Fuegian population, "jaurías ${ }^{4}$ dañinas" 5 [dangerous packs] that are economically harmful to the province. These wild dogs attack and kill sheep and rams, which are essential to Fuegian livestock, and threaten certain tourist activities due to the risk they pose to tourists, and to sled dogs when they attack criaderos ${ }^{6}$.

The Tierra del Fuego archipelago is formed by the "Isla Grande" (48,00o sq kms) and more than 200 small islands. Isla Grande has three cities - Ushuaia, Tolhuin and Río Grande - with a total of around 127 thousand human inhabitants according to the 2011 Argentine National Census, and more than 50 thousand canine inhabitants (according to Ushuaia's Zoonosis Department).

\footnotetext{
1 Research funded by the São Paulo State Research Support Foundation (FAPESP): “Cães, trenós e humanos: uma etnografia multiespecífica em Ushuaia (capital da Província da Terra do Fogo/Argentina)". [Dogs, Sleds and Humans: a multispecific ethnography in Ushuaia (capital of Tierra del Fuego province/ Argentina)]. File number: 2017/13073-7.

2 This article is the result of a paper presented at the VII ReACT - Anthropology of Science and Technology Meeting, which took place in Florianópolis (Santa Catarina/Brazil) from May 7 to 10, 2018, entitled "About sled dogs and perros salvajes: what can a dog in Tierra del Fuego". I am therefore very grateful to the coordinators and debaters of the Working Group, for their careful reading and many suggestions.

3 In Spanish, "perros salvajes" or "perros asilvestrados".

4 "Jauría", in the Diccionario mini de la lengua española Larousse, is defined as a "set of dogs that hunt together". In this context, the term has a negative connotation, something like canine "gangs", as suggested by Santos (2018) among the Guarani-Mbya in Jaraguá (São Paulo/São Paulo/Brazil). The Portuguese translation, in the Dicionário Michaelis, is "pack".

5 Linguistic note: in this article, all direct quotes from my interlocutors, in addition to some terms in Spanish, were transcribed and kept in the original language. The indirect quotations, in turn, were translated and left in quotation marks. Finally, terms in other languages, as well as nominal terms, were left in italics - both in text's body and in footnotes.

6 Criaderos are places where sled dogs are bred and sled tours take place. An English translation would be "breeding place", but in this article I chose to leave the term in its original language.
} 
Map 1. The Tierra del Fuego archipelago



Source: Google Maps, 2018

Dogs in Tierra del Fuego may be companion animals, sled pullers, "runaways" and even abandoned animals - not by law, of course, but the many animals roaming the streets of Ushuaia, as well as the statements by humans that I met during the field research, point to certain "slovenly" conditions or "inefficiency" in "solving" the problem of abandoned domestic animals. Similar to what was suggested to Osório (2013: 157), who worked with animal protection groups, in Ushuaia I often heard that "street animals are abandoned animals, and animals with owners that have access to the street are animals that are not managed by responsible ownership". This "responsible ownership", however, which involves affection and care for dogs and therefore their control - be they companion animals, sled dogs or stray dogs - is not extended to wild dogs that inhabit rural areas and regions uninhabited (by humans) in Tierra del Fuego. It seemed that the Fuegian population tends to be more concerned with the "perros aselvajados" and the economic and social problems they supposedly provoke than with dogs abandoned to the streets.

In Ushuaia, those who dislike the practice of dog sledding, who proclaim that "perros no son caballos, no son animales de carga" [dogs are not horses, they are not draft animals] (and who said horses are draft animals?), are the same as those who defend the control (read extermination) of wild dogs and demand solutions for the "poor" dogs that live on the city streets. On the other hand, for those who practice mushing' and work directly with sled dogs, that is, who do not consider canine work to be mistreatment or exploitation, wild dogs also represent a threat that must be "controlled", since they can put their dogs and tourists at risk. Except when a wild dog ceases to be wild; when, for instance, a wild dog pup appears alone near a criadero, and is "adopted" and trained to be a sled dog - in other words, a working dog. In this sense, from the moment dogs learn to pull a sled, that is, when they learn to work, they abandon their conditions as "wild" dogs, as an "animal dañino" and as an "invasive alien species" (Schiavini \& Narbaiza 2015) and becomes a working dog. Conversely, let us not forget, wild dogs owe their status to the fact that they do not work: as Porcher and Nicod (2019: 255) wrote, "putting animals out of work is putting them out of their relations with humans and sentencing them to a costly freedom with many consequences".

"Mushing" is the term that refers to the practice of sledding. There is no translation into Portuguese. 
Why are dogs that are not under human control not considered as companion animals or work animals but as "invasive alien species" and a threat to economy, as has been happening in Tierra del Fuego with feral dogs? And why do these dogs, when trained to be sled dogs by both humans and other dogs, as I will discuss later, regain the status of domestic animals and, consequently, become eligible for commiseration, appreciation, care and other (human) feelings? In short, why, in that context, is there no compassion for wild dogs? It is worth pointing out that the classification of these dogs as "wild" was determined by humans, since the first packs of wild dogs in the region arose due to the numerous abandonments of domestic dogs in uninhabited areas of the province. So, the question is: what do Fuegians mean by "wild"? It seems in this scenario what is considered "wild" is more of a human product than a "natural" condition.

In this paper, I suggest that the lines dividing sled dogs and feral dogs in Tierra del Fuego particularly concern animal work - and the practices and techniques involved in the assemblage of mushing. Work, here, as well as its learning and execution, seems to be the aspect that allows dogs to enter (or be excluded from) the domain of what, apparently, is exclusively human. Sled dogs are born, grow and spend their lives in the criaderos; day in and day out, they wake up, eat, work, play, eat again and sleep. As Piero Leirner suggested (in a personal communication), their routine resembles that of English workers in the eighteenth and nineteenth centuries.

Apart from criticism about canine work, mainly from tourists but also from the Fuegians themselves - for whom, as a rule, dogs are not "draft animals" - I propose here to use my ethnographic context to particularly consider the domestic/wild dichotomy and its porosity. Moreover, since sled dogs and their relationship with humans - mushers ${ }^{8}$ and tourists - are the main theme of my research, I also intend to explore these relationships to reveal the different techniques and practices that involve them. Roughly speaking, "novice" sled dogs learn to pull a sled from both the mushers and the "veteran" dogs. They learn, on one hand, because they are "natural" sled pullers; they are, in the words of Hugo Flores, the owner of Criadero Siberianos de Fuego and my main contact in the field research, "entrenados con genética" - and human control over canine reproduction is central to this line of reasoning. On the other hand, however, sled dogs learn by doing, "tirando un trineo", and watching other dogs doing the same activity; they learn mainly because of the discipline demanded by other dogs (with barks, growls, looks and bites) that they experience in practice.

Working dogs, for Cummins (2009:119), are those that "are bred and trained for specific functions for human kind". In this sense, dogs that do not occupy any social "position", such as feral dogs, cease to be "man's best friend" and become an "invasive alien species". It doesn't matter how they became feral - in this case, because they were abandoned. What really matters, for those humans who work in the criaderos and for tourists and the Fuegian population, is that the "problem" be solved - except in cases where puppies of feral dogs join and are incorporated into the "team", that is, are trained to be working dogs. Unlike sled dogs, which for mushers are strictly working animals and which many tourists see as companion animals or family members that shouldn't be draft animals, feral dogs are unanimously seen as trouble. As suggested by Digard, "the boundary between the wild and the domestic is not always between species, but also within species" (2012:212, italics in the original).

This article has two sections. In the first, I consider feral dogs, their status as "harmful animals" and their “impacts" on the Tierra del Fuego economy. Secondly, I explore Siberianos de Fuego's 137 sled dogs - Siberianos was the main site of my research - in an effort to reveal what animal work, in this case, reveals about the domestic/wild dichotomy. I also try to identify the concept of domestication held by the mushers who work in Siberianos. For these mushers, domestication involves practices that are mediated by a technical artifact - the sled - and are part of a working relationship that involves, in addition to control and domination, love and care. As Tsing (2012:141) pointed out, "domination, domestication, and love are deeply entangled".

\footnotetext{
8 At least in tourism and sports, "musher" is the term used to designate the human who drives the sled. There is no equivalent term in Portuguese.

9 "Equipo" (in English, "team") is the term used by mushers to designate the encounter between dogs, sleds and humans: thus, musher, sled dogs and sled make up "un equipo".
} 
Moreover, recognizing that there are many forms of work (Vatin 2019), even animal work (Sigaut 2007), and that it goes far beyond the human - as Porcher and Nicod (2019:252) wisely noted, "animals actually work" allows us to think of the working relationship between humans and animals as relationships that go beyond production, market and exploration:

Let us remember that the concept of labor does not refer only to relations of coercion, exploitation and domination, even if the working relationships between bosses and workers and between humans and animals are asymmetrical. Working with humans as with animals is first of all living together and being engaged together in a productive activity of value (...) animals engage their subjectivity and their affectivity in the work. They demonstrate their agentivity (Porcher \& Nicod 2019:255).

As stated by Swanson, Lien and Ween (2018:13), relationships of domestication "are not always captured by classic notions of human mastery and control". In this paper, I suggest that in Siberianos de Fuego dogs and mushers domesticate each other through coexistence, observation and an "education for attention" (Ingold 2000). Driving and pulling a sled are practices that require constant training in paying attention (Grasseni 2005): on the one hand, dogs must always be attentive to the commands of mushers and the signs from their canine companions (their barking, growling and even looks), to pull the sled correctly and work as a team. On the other hand, to "genetically train" the animals, mushers must know how to perceive in them (when they're pulling a sled, ${ }^{10}$ of course) the morphological and behavioral traits they want to maintain, and this requires a skillful vision, acquired and perfected day to day - as Grasseni (2005:44) pointed out in her research context, "skilled vision is invariably the result of training".

To domesticate, therefore, is to codomesticate: as Fijn (2011) suggested in her ethnography with shepherds in Mongolia, I propose here that sled dogs and mushers in Ushuaia domesticate each other through mutual teaching and learning practices. In a "continuous action" (Digard 2012), together, humans and animals make such a working relationship possible: as Grasseni (2005:45) affirmed, learning is a social process of co-participation. In South America's extreme south, work domesticates.

As a guide to the ethnographic case presented here, one of the suggestions made by Swanson, Lien and Ween (2018:4) in "Domestication gone wild" is that in multispecific studies we need to decentralize the traditional domestication narratives and recentralize our analyses in the "continuous domestication practices". In this paper's final remarks, I return to these questions in an attempt to seek address the many ambiguities that arise when we think about these dogs in Tierra del Fuego through a reflection on animal work, which involves different dogs at different conjunctures - and reveals how different material semiotic practices related to dogs produce different statuses of dogs (Lien \& Law 2011). I suggest that the lines dividing sled dogs and feral dogs (which separate, after all, the domestic and the wild) - as well as other types of dogs, such as stray dogs and companion dogs - have a particular relation to animal work and to the practices and techniques involved in this very particular assemblage - the mushing, at least in Tierra del Fuego. Work thus defines the status of dogs (of all types) in this region of the planet.

\footnotetext{
10 Like Grasseni (2005) in her ethnography with dairy cows in Italy, I suggest here that the sled, in relations to humans and dogs, acts as an artifact for technical mediation, since it's through it, for instance, that the mushers train their "selective vision" - or, as Ingold would say, their "skills" - and become able to perceive which dogs are good pullers and, consequently, "good for breeding". In addition, the sled also operates as a communication vehicle, a translator, so to speak, between human and canine languages - in a general semiosis, in Kohn's sense (2013), and as a word-tool (Ingold 20oo).
} 


\section{The abandonment of dogs in Ushuaia and wild dogs: dogs classified as "invasive alien species"}

I landed in Ushuaia on the 5 August 2018, around nine in the morning. In my first days in the city, it was nearly impossible not to notice the many dogs roaming the streets, whether downtown or at the outskirts. Do these dogs have owners? Are they abandoned dogs? Talking to Aixa, my landlady in Ushuaia, and Ariel, the gentleman who drove me to the "winter centers" "perros callejeros".

According to Aixa, Ushuaia has a big problem with abandoned dogs, since civic projects and municipal ordinances aimed at maintaining and caring for these animals have not been successful. Free services offered by the city's Zoonosis Department, such as sterilization and chip implantation, as well as fines for those who leave their dogs loose on the streets, are not sufficiently employed and enforced. Her dog Negro, a seven-year-old Labrador, for example, was abandoned before she adopted him. Moreover, as Ariel told me, "Ushuaia es una ciudad con mucha gente en tránsito, gente que vino a trabajar, se queda sin trabajo y se va. Y dejan sus perros tirados".

The problem of abandoned dogs in Ushuaia is not recent: the first records of attacks by wild dogs date back to the 197os (Schiavini \& Narbaiza 2015). Both Aixa and Ariel mentioned, in addition to stray dogs, the "jaurías de perros salvajes". They said that the "jaurías" are composed of very aggressive dogs that constantly kill animals on farms, such as horses, sheep and cows, and also attack humans. According to Ariel, these are dogs that descended from abandoned city dogs, which have been breeding alone for many generations, and are born and live without human contact and control:

La gente los lleva de la ciudad y los tira, porque ya no los quieren. Los llevan al campo, los tiran, y el animal, después, sobrevive, y se hace salvaje, se conforma una manada, busca a un macho alfa.

Lo que pasa es que en la isla hay una zona llamada Península Mitre. Esta zona está deshabitada prácticamente, es salvaje. Entonces hay mucho animal que ha ido a este lugar y se criado solo. Hay no solo perros, hay caballos salvajes, hay toros y vacas salvajes. Ocho mil cabezas de ganado asilvestrado, de acuerdo con los estancieros. Y ellos se van reproduciendo. Y lo mismo pasa con los perros. Una vez que ellos se adaptan al lugar, también van se reproduciendo de manera exponencial (Ariel).

According to Argentina's 2011 national census ${ }^{12}$, Tierra del Fuego has around 127 thousand inhabitants, of which 57 thousand live in Ushuaia, 66 thousand in Río Grande, three thousand in Tolhuin and 1,200 in rural areas farther from the urban centers. On the other hand, Ushuaia's Zoonosis Department ${ }^{13}$ estimates that there are more than 18,000 dogs in town, although it is not known how many have owners and how many do not - in Río Grande there are around 33,00o dogs. During my field research I visited Tolhuin, approximately 100 kilometers from Ushuaia, where the abandonment of dogs and the lack of a municipal kennel has led to an overabundance of animals in terrible health conditions wandering hopelessly in the streets.

In Ushuaia, the Zoonosis Department provides free castration, registration and animal identification through microchip implantation (which is mandatory for domestic dogs) ${ }^{14}$, adoption assistance and broad spectrum antiparasitic agents. Moreover, the Department is also responsible for control of unaccompanied dogs on public roads and spaces. Municipal Ordinance No. 480o, sanctioned on December 10, 2014,

\footnotetext{
11 Winter centers are large tourist complexes that offer a variety of activities - such as dog sledding, snowmobiling and snowshoeing. Each activity is usually administered separately by individuals or tourist agencies.

12 Available in: <https:/|www.indec.gov.ar/>.

13 For more information: 〈https://www.ushuaia.gob.ar/zoonosis $>$.

4 For cats there is a charge for the same service, which is optional.
} 
regulates the "responsible ownership of domestic species (dogs and cats) that humans use as company". Beyond National Law $14.346^{15}$, which states that a pet's owner must provide "food, drink, healthcare, and the basic facilities for physiological needs", the ordinance stipulates, among its 41 articles:

$7^{\text {th }}$ Article - It is expressly forbidden: a) the circulation of DCA [domestic companion animals] on public thoroughfares unaccompanied by their owners; b) the circulation of dogs accompanied by their owners but without collar and leash ${ }^{16}$.

Although non-compliance results in fines and other penalties, these measures in practice do not appear to be effective for solving the issue of dogs on streets. Furthermore, according to Ariel, dogs in Ushuaia are very much "runaways" because "sus dueños no dan cuenta de mantenerlos presos [en sus casas]". For instance, Negro, the Labrador dog, spent hours every day loose on the streets without his owners - in addition to frequently escaping, he was often deliberately released. Therefore, the issue goes far beyond what we commonly call "abandonment", since Negro was not an abandoned dog, nor was he mistreated.

As mentioned, dogs in Tierra del Fuego are also often abandoned in rural and uninhabited areas:

The domestic dog is an integral part of urban and rural communities. However, loose and abandoned dogs worldwide do not have the necessary food, shelter and health care, and generate impacts on society affecting public health, the environment and productive activities. In rural areas the problem is exacerbated by the conversion of loose dogs into feral dogs, which do not depend on man for livelihood, shelter and reproduction (Schiavini \& Narbaiza 2015:1).

Feral dogs, more than a social problem - and which in fact did not seem to be a significant cause of concern to civil animal protection associations - seem to be an economic issue in Tierra del Fuego, since "the impact of feral dogs has forced most of the ecotone establishments to convert livestock activity from sheep to cattle" (Schiavini \& Narbaiza 2015:4). Due to frequent canine attacks on livestock, farmers are unable to breed sheep, a species that "traditionally" characterizes Patagonia - but are also animals that were introduced like sled dogs! - and are beginning to raise cattle. Furthermore, these dogs came to be classified as "invasive alien species", alongside other non-native animals, such as beavers, muskrats and gray foxes:

More recently, in October 2014, the Provincial Environment Council issued a Dictate declaring a social-environmental emergency in Tierra del Fuego due to problems generated by loose and feral dogs, characterizing them as an “invasive alien species" (Schiavini \& Narbaiza 2015:5).

Therefore, the dog as "invasive alien species" ceases to be a pet, "una mascota", or a work animal, which leads us to believe that the definition of "invasive alien species" has nothing to do with the origin of animals, but is determined by their effects and how these effects are seen by humans. As Sordi (2017) suggested in his research with wild boars in the Campanha gaúcha region (Rio Grande do Sul state, Brazil):

what is the "native" of a certain ecological orthodoxy if not a particular regime of domesticity, an imaginary ecumene where each species occupies its own niche and plays a determined role in maintaining an oikonomy (Agamben 2011) of nature as a harmonic totality? Conversely, what is the "exotic" if not an exteriority that threatens this ecumene through the dangers of intrusion and condemnation? (Sordi 2017:287-288).

As such, what is (and what is no longer) "exotic", in the context of dogs in Tierra del Fuego, depending on their social-economic role (or the absence of such a role)? Sled dogs, although nonautochthonous, are a tourist symbol; loose dogs, those with no human control, are harmful animals, pests.

\footnotetext{
Available in: <http://servicios.infoleg.gob.ar〉.

Available in: <http://www.concejoushuaia.com>
} 
Fuegian sheep breeders even use guard (working) dogs to defend their flocks from attacks by feral dogs! ${ }^{17}$ These dogs are bred and trained for that task, and although the number of guard dogs in Tierra del Fuego is still very small, we see a situation in which dogs are especially trained to protect herds and attack (even eliminate) other dogs. Furthermore, Ariel, who is retired from the military, told me that when he was working in the Argentine Army and training in remote regions of the Island, farmers told him that if or when he saw a wild dog, or a pack, he should shoot and kill them immediately.

Figure 1. Warning sign on a farm in Tierra del Fuego



Source: La Nación, 2018

What's a dog without a human? It seems in this context that dogs that breed and live without human control become "trouble", "infractors" and "omnivorous predators and scavengers", as well as a risk to tourists who enter the Fuegian forests (Schiavini \& Narbaiza 2015). According to Porcher and Nicod (2019:253), "this reversion [by domesticated animals] to their wild status is in fact the consequence of the release of these animals from labour". In this paper, I suggest precisely this. Moreover, dogs without work (whether in family homes, the countryside or the criaderos) are expendable dogs.

I propose here that the feral dogs in Tierra del Fuego are, as suggested by Sordi (2017) and Digard (2012) in other contexts, animals that have gone through a process of feralization or marronage. Like Sordi, I suggest that wild dogs in Tierra del Fuego indicate not a dichotomy between the domestic and the wild, but the porosity of domesticity (from which these animals were apparently excluded):

the feral isn't the opposite of the domestic - a role played by the wild - but the indication of its fissures and contradictions. Thus, more than anything, the feral is the way in which the wild inhabits domesticity from within, and not the encounter or hybridization between two distinct domains (Sordi 2017:288, italics in the original).

Morey (2010:199) affirmed that "dogs simply do not thrive when deprived of regular human care and interaction". Following this logic, the mushers in Ushuaia say that feral dogs cease to be feral the moment they learn to pull a sled - the moment they learn to work. For instance, Siberianos de Fuego has Lonely, a wild dog that was found alone when still a puppy near the criadero, and was trained to pull a sled, and Bigote,

17 Because I lack enough data, I will not discuss protective dogs in this paper. 
who is the result of a cross between a female Alaskan Husky ${ }^{18}$ from Siberianos and a wild dog, which had managed to invade the enclosed kennels in which females in heat are confined. However, contrary to what was suggested by Morey and by the mushers in Ushuaia, the growing number of feral dogs in Tierra del Fuego seems to be pointing to another outcome. In 2012, more than 1,200 feral dogs were registered, and it's estimated that the numbers are even larger (Schiavini \& Narbaiza 2015). Dogs, then, do not (necessarily) need human companionship to “thrive” (Morey's words).

Just as Old-World farm animals thrived in the "Neo-Europes", in a "wild" and "semi-domestic" state (Crosby 2011), and beyond the control of Europeans, feral dogs, gray foxes and beavers currently thrive in Tierra del Fuego - even if, contrary to what the "myopic" idealism (Digard 2012) of animal welfare movements (Porcher \& Nicod 2019) suppose, their lives are not easy. For instance, although they are constantly chased by humans, wild dogs maintain "commensalism interactions with the gray fox ${ }^{19}$, another exotic species, and with scavenger birds” (Schiavini \& Narbaiza 2015:3).

Figure 2. Bigote, part Alaskan Husky, part wild dog. Criadero Siberianos de Fuego

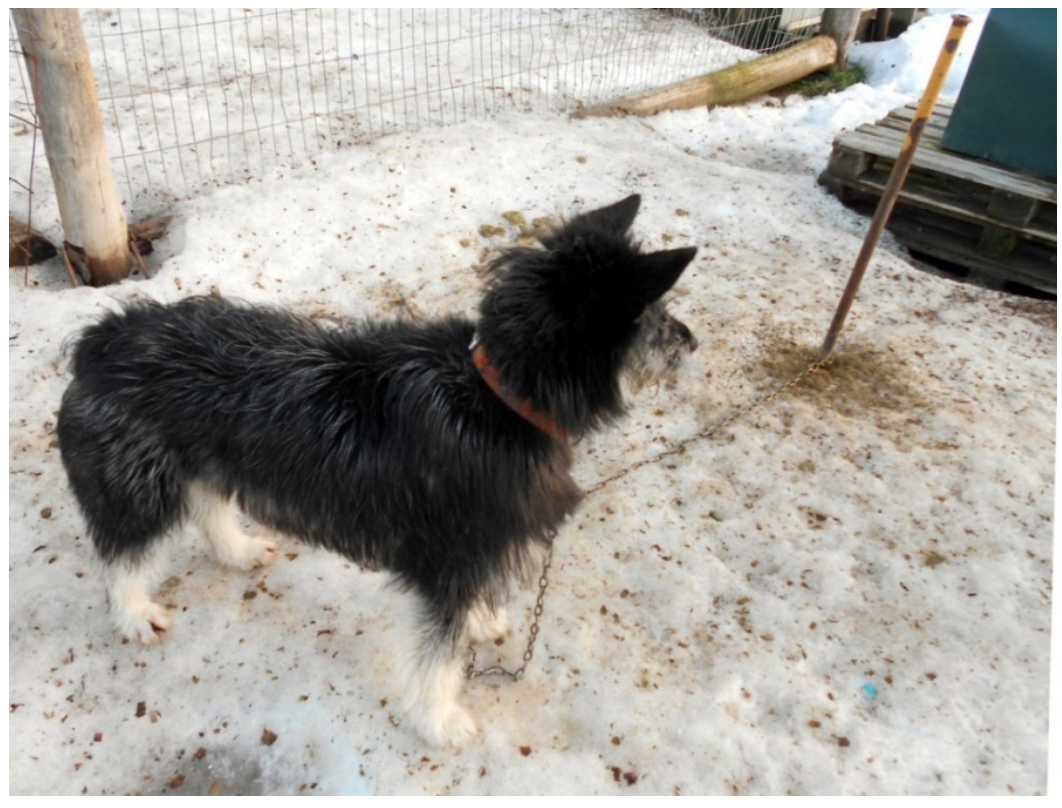

Photo by the author, 2018

In Ushuaia, if on one hand feral dogs place some economic activities at risk, such as husbandry and tourism, on the other, there's the enthusiastic fomentation of mushing - tourists love it! In this sense, the status of a dog derives from the set of different material and semiotic encounters and practices between humans and non-humans: as suggested by Lien and Law (2011:70, original italics), "if an object (...) emerges in the relations of practice, then we need to remember that there are many practices". Wild dogs became "wild" through abandonment by humans. In Tierra del Fuego there seems to be no room for them. It seems that the idea of a "perro salvaje" does not make sense (considering that dogs are man's best friends) and, therefore, must be (or is likely to be) eliminated. Sled dogs, in turn, despite being an exotic species (like the sled itself), are a very profitable tourist symbol. As mushers suggested to me several times, these dogs are (or are in the process of becoming) native animals. They already are, like the mushing, "part of the Patagonian culture".

\footnotetext{
18 The Alaskan Husky is the canine breed most used to pull sleds today, either in tourism or competitions. It is not an officially recognized breed by the international cynological federations.

19 The gray fox was introduced in Tierra del Fuego in the early $20^{\text {th }}$ century.
} 
As the main theme of my research, sled dogs are the subjects of the next section. From being considered "invaders" and "pests" to having their images on T-shirts', snow globes and other souvenirs, what are the possible statuses of dogs in Tierra del Fuego?

\section{Sled dogs: between the innate and the acquired, the ability to pull}

Dogs' roles have been multifaceted, and they have not been passive raw material to the action of others. Further, dogs have not been unchangeable animals confined to the supposedly ahistorical order of nature. Nor have people emerged unaltered from the interactions. Relations are constitutive; dogs and people are emergent as historical beings, as subjects and objects to each other, precisely through the verbs of their relating. People and dogs emerge as mutually adapted partners in the naturecultures of lively capital (Haraway 2008:62).

My mornings at Criadero Siberianos de Fuego, one of the four sled dog criaderos in Ushuaia, always had a resounding start. Around ten o'clock, after the dogs were fed and the kennels cleaned, the mushers were in charge of preparing the five sledges for the tours that would soon begin with the arrival of the first tourists. Simultaneously, the 137 sled dogs who live there began to bark uninterruptedly in an unusual canine symphony. For Hugo Flores, the owner of Siberianos ${ }^{20}$, the dogs were enthusiastically saying "I want to run!", "Let's run!"

Figure 3. The Criadero Siberianos de Fuego



Photo by the author, 2018

For Flores and the four other mushers who work there - his two sons, Leonardo and Nahuel Flores, as well as Jorge and Hernan -, the "nature" of these dogs is defined by work. From the mushers' perspective, these are dogs that "genetically" and "ancestrally" love to run - and therefore, to work. For the mushers, what defines these dogs as work animals is their "natural need" to run and pull: pulling a sled (i.e., working), is thus seen as a way to satisfy a "natural" canine need. Moreover, training these dogs consists mainly of preparing them genetically - as much as the idea seems paradoxical - so that they're good sled pullers.

20 According to Hugo, the tourist practice of mushing in Ushuaia began in 1991, and he has been working there since 1999, when he moved from Río Grande (Tierra del Fuego province) and had a team of only 27 dogs. Furthermore, Siberianos de Fuego is the only criadero in Ushuaia in which the owner cares for the dogs and leads this care. 
To do so, the mushers spend months observing the animals, to select for the crossings those that have the best traits (such as stamina, strength, intelligence and concentration) - that is, those who can generate good sled pullers. Siberianos de Fuego is thus like a large open-air laboratory. This was also noticed by Leal (2018:39) with cattle and cattle breeders in Brazil: "in zootechnics, it was the practitioners - breeders - who opened the way for the theorists. The farms, in this way, were the biggest laboratories of the zootechnicians".

On the one hand, mushers and dogs need, for the mushing to be possible, a close relationship based on "trust", "feeling", mutual understanding and incessant communication - mushers through not necessarily verbal commands and dogs through grunts, barks and body signals. Sled dogs and mushers get to know each other especially by living together and observing each other's actions. On the other hand, the use of mushing as a tourist activity is an economic activity, and the dogs are thus, in Miguel' $\mathrm{s}^{21}$ words, "parte del negocio" [part of the business]. However, even "goods" can be loved and cared for (Vander Velden 2018), and the commercialization of animals is a fundamental issue for the discussion of animal work (and, here, especially for dogs), since these animals are not just goods, with use and exchange value, but also types of capital goods - "lively capital", as suggested by Haraway (2008) -, since they make (and are worth) money. In the words of Porcher and Nicod (2019:255), even though the relationship is asymmetric, "working with humans as with animals is first of all living together and being engaged together in a productive activity of value". But note that no one is affirming that working relations between humans and animals are symmetrical, or that they are free from exploitation, domination and control.

In contrast, the relationship between sled dogs and tourists is characterized both by a market fetish and the dogs' "humanization" as the mushers say. Tourists may see the dogs as "poor wretches who work all day" and therefore as victims of "inhumanity", but they are also seen as beautiful and "exotic" animals. As I often observed, many tourists were extremely disappointed when they discovered that their sleds would not be pulled only by the beautiful and (apparently) "untamable" Siberian Huskies. Among tourists, therefore, the most important factor is the animals' aesthetics - their value comes from their "exotic" traits, since Siberian Huskies are one of the oldest known breeds (Fogle 2009) and are very similar to wolves. In the field, I often heard tourists extolling Siberian Huskies' beauty: “I want this one for me, he has blue eyes, look!”; “This is just to decorate the place"; "Poor guy, so beautiful, and he's here to work"; “Take a picture of this one, he's wonderful!"; and so on. In this context, whether dogs are "part of the team" or the product of "genetic improvement", fetishized goods or "pets", they assume, in their relations with both mushers and tourists, different roles - as Vander Velden affirmed (2012), dogs by definition have an ambiguous status ${ }^{22}$.

Mushers and dogs form a "team", which according to Hugo needs to be "siempre en sintonía, siempre en comunicación, es necesario que haya un feeling, una relación de confianza entre perros y mushers". This relationship, moreover, must be built on a daily basis: it's through continuous coexistence, through "living together", that dogs and mushers get to know each other. One of the mushers told me that between them and the dogs "la relación es metafísica, no se explica con palabras". The relationship is more than corporal and, for this reason it is necessary to create (dogs and humans, together) a new form of communication that transcends verbal language - that is capable of capturing, for instance, the animals' likes and dislikes in just one look. As Brandt (2004) proposed in her research context with horses, I suggest that in Ushuaia sled dogs and mushers co-create a third language, a "language of their own":

\footnotetext{
21 Miguel was another musher that I had the opportunity to meet during my field research.

22 For the purposes of this article, and because of a lack of space, I will not focus on discussions about the relationship between sled dogs and tourists, or those between the animals and the mushers. I will develop these reflections in another paper (forthcoming).
} 
animals communicate their feelings and desires to their human partners in a myriad of ways, lacking only the capacity to do so through the spoken word. By recognizing non-verbal forms of communication, an exploration and understanding of how humans and their nonhuman animal companions can come to know the "subjective presence of the other" becomes possible (Brandt 2004:302).

At Siberianos de Fuego, the day begins at eight am, when the dogs are fed balanced food rations and scraps of lamb. Around ten, when the first tourists arrive, the sled tours begin. The animals are attached to the sleds (six to ten dogs per sled, depending on the amount of snow on the trail), and the route, of approximately fourand-a-half kilometers, takes about twenty minutes. Dogs rest for about ten to fifteen minutes between each tour; they lie down, play, bark, and sometimes fight. Mushers, on the other hand, keep constantly checking the animals and the sleds, making sure the dogs are comfortable and the sleds in shipshape. Furthermore, they only replace dogs on the sleds if they get hurt or do not want to run anymore (when they lie down and do not show any desire to get up), when they're tired or take the maximum six daily turns. Leonardo told me that "el musher es como un director técnico, y por eso necesitamos estar siempre atentos con nuestro equipo". It is very interesting to think about the notion of "team" in this context and the relationship between dogs, mushers and sleds. For the practice of mushing to be possible, mushers and dogs must correctly coordinate this very particular "dance of encounters" (Haraway 2008).

As good and experienced as a musher may be, a sled without canine traction does not move - on the other hand, a sled can travel with canine traction and without human guidance: but why would dogs pull a sled without human presence? Who would they be pulling the sled for? Agency, therefore, takes place in the performance of the trio; it emerges and is distributed in the relationship. It is, after all, a cyborg, who must always follow a very and (multi) specific choreography to achieve what it sets out to do. Technique is not just about a technical object; rather, it concerns an objectification of the technique - from a cooperative relationship at work:

No work collective is efficient without the coordination that stems from procedures, but, additionally, no collective is effective without cooperation. Cooperation cannot be imposed, it is a conditional on individual freedom. An animal that does not want to cooperate cannot be constrained to do so. It can be forced by threats or by violence, but it can obey, as industrial farm workers know very well, while refusing acquiescence (Porcher 2014:6).

According to Jorge, the only consensus among the mushers is that all of them "necesitan conocer a sus perros muy bien, y siempre entender lo que quieren decir con sus gestos" - and this knowledge emerges, as already mentioned, from living together and observing each other. The importance of knowing the dogs, the respect for their abilities, the two-way communication that's established between dogs and humans and the importance of trust and partnership in the relationship were some of the themes explored by Kuhl (2011: 22) in her research with mushers and sled dogs in the Northern Hemisphere. All the aforementioned aspects, which emerged in Kuhl's conversations with the mushers, also arose in Ushuaia. As I was told in Siberianos, each dog has a personality - and therefore it is essential to know them individually, the "character" of each one, and each one's likes and dislikes, their friendships and enmities, in order to achieve a good relationship between dogs and mushers. There are "jealous", "smart", "silly", "good” and even "deceptive" dogs. In this sense, for mushing to occur mushers and dogs must get to know each other and make themselves known, establish a relationship of mutual trust and a communication that's intelligible to both. As Kuhl (2011:26) also stated, "because the mushers felt their dogs to be individuals with personalities, 'you need to get to know them' was a phrase I heard often when mushers spoke of the elements of a good musher-sled dog relationship". 
According to Hernan, you're not taught to be a musher, and to learn the practice "el principal es gustar de perros y que ellos te acepten". Furthermore, it's through observation that the practical foundations of mushing are transmitted, just as happens among dogs themselves when learning to pull a sled: they learn mainly by observing each other, but also through barking, grunting, growling and biting. As Vander Velden (2016) pointed out, the idea that you learn by doing is something that often emerges in hunting contexts with dogs - for instance, the Karitiana in Rondônia: "Human hunters must make their dogs good hunters, through a set of procedures (...) 'do', more than 'teach' - as we think of the training of dogs among us - because dogs actually learn to hunt in practice" (Vander Velden 2016: 28).

Besides, unlike what usually happens with pet dogs, "adiestrados específicamente por los humanos" (according to Jorge), sled dogs learn the technique from each other. As Joel, a musher in another criadero in Ushuaia told me:

Para enseñarles, colocamos los cachorro ${ }^{23}$ en el trineo junto con perros experimentados, para que éstos enseñen a los principiantes. Es a través de miradas, olores y ladridos que los perros se enseñan unos a otros. Nosotros enseñamos los comandos, los perros enseñan a tirar. Y formamos un equipo (Joel).

The mushers also told me that when the dogs are about one year old, when they're both physically and mentally developed, they're attached to the sled with experienced dogs and trained to pull, both by the musher and by the "veteran" dogs. They learn to work as a team. Furthermore, according to Hugo "los perros-guía ${ }^{24}$ más viejos y experimentados, como Luna [a nine-year-old Alaskan Husky], enseñan y nos ayudan a enseñar a los perros jóvenes a convertirse en perros-guía". In this context, when the mushers speak of "entrenamiento" and "entrenar", they're referring to the sled rides themselves, since the practices of training and mushing are simultaneous: you (whether you're a human or a dog) learn by doing. As Vander Velden suggested about hunting dogs among the Karitiana, "training, in fact, seems to take place only in the forest, during hunts, and not only with human hunters but, above all, with other dogs already experienced in the techniques of searching, chasing and killing" (2016:30).

This "canine education" is also present in the relationship between "retired" dogs and those who still work. For instance, Sara, a twelve-year-old Alaskan Husky, was retired. One day she was released and began to run among the other dogs. According to Hugo, she was "greeting them":

Mira, Sara fue suelta y está feliz, saludando a los otros [cães]. Ellos están agitados, ladrando. Y cuando se acerca, siempre feliz y sacudiendo la cola, ellos se tranquilizan, ¿ve? Pero cuando empezaren los paseos ella tendrá que ser nuevamente presa, sino va a correr detrás del trineo porque quiere tirar también. Quiere participar (Hugo).

She, Hummer and Gema, who are also retired Alaskan Huskies (ages thirteen and fifteen, respectively), are dogs whose task is, according to Hugo, to "enseñar a los demás perros a seren tranquilos unos con otros":

Gema y Hummer son los dos perros más viejos. Ellos tienen como función enseñar a los otros perros a socializar. Andan entre todos, sueltos y tranquilos, y transmiten buenas energías y tranquilidad. Así los perros aprenden a pelear menos y quedarse tranquilos entre ellos (Hernan).

However, Hugo told me that this teaching - or, as Ingold suggested (2000), this "education for attention" results mainly from the dogs' ancestry. According to Hugo, they're dogs that genetically and instinctively like to and are inclined to run: it's as if the dogs' tastes and habits are in their genes and came from their ancestors. So, for the mushers, the very "education for attention", the practical teaching that takes place among the dogs

\footnotetext{
23 In Spanish, the puppies of any mammal (including dogs, of course) are called "cachorros".

24 Leader dogs, or guide dogs, are those who go in the front positions of the sled. According to the mushers, they're the most intelligent dogs since they have to guide the other animals behind them.
} 
themselves, is, at least in part, a consequence of the genetic makeup - and also the genetic manipulation - of these animals. In Hugo's words, “entrenamos los perros con genética, y entrenar con genética es como hacer un plan previo". He then takes responsibility for maintaining the "nature" ${ }^{25}$ of these dogs that are "originally" sled pullers and have an "instinctive need" to run and pull.

In Siberianos, training sled dogs consists mainly of preparing them genetically for sled practice - this relationship would be close to what Leach (2007:91) called the "third stage of domestication", in which "methodical selection pressures were added as breeders learned how to improve and 'fix' breeds". Nevertheless, the relevance of this manipulation of canine genetics revealed in the mushers' statements and practices, as well as the empirical results of this technology (namely, the animals' controlled reproduction), differs from genetic laboratory technologies - although they are equally complex and efficient. While the statements and principles used are basically the same, the criaderos' experiences are supported by observation - of the "observed talent" (Coppinger \& Schneider 2017:24) - and conviviality, not by laboratory research. Although the language (the framework) of the Criadero is that of a genetics' laboratory. This was also noticed by Leal (2018) with cattle breeders in Brazil.

The mushers told me that dogs, whether Siberian or Alaskan Huskies ${ }^{26}$, are dogs that "ancestrally love to run". I emphasize, for my purposes, that the term "genetics" in this context refers both to a "genetic improvement" (a technique to optimize the dogs' performance in the work of pulling a sled) and to the animals' "nature" (their "inherent characteristics" and "ancestral past"). Phrases like "abrimos la genética de los perros" and "es su naturaleza, su herencia de los lobos" were constantly repeated by the mushers. Thus, in this context, the "relational dimension" (Sautchuk \& Stoeckli 2012:228) of the term "genetics" and, consequently of domestication, as well as its ambiguous condition, is something worth noting. On one hand, the sled dogs' "original past" is a past in which they were already domesticated. On the other hand, the dogs are "morphologically domesticated" (Ingold 1980:82) through genetic improvement and controlled reproduction - that is, "selective pressures" (Fijn 2018; Stépanoff \& Vigne 2019).

According to Hugo, due to dogs' lupine ancestry - especially "Nordic dogs", a category used by Hugo to refer to "pure" sled dogs, such as the Siberian Husky - the behavior of these dogs is "similar to wolf behavior". For the mushers, to live as a big family, to enjoy running (what is to enjoy running for a dog? Or a wolf?), demarcate territory and have an alpha leader (who in this context is human) are all genetically inherited traits of wolves. To be "wild" in this case, differently from that of the perros salvajes, adds value; "el aullido de los perros de trineo es un legado de los lobos", and, like wolves, these dogs, when they return from a sled run, like to demarcate territory, "como si estuvieran en un nuevo lugar, aún inexplorado":

La línea de los perros nórdicos, lo único que les interesa es vivir en jauría, estar en un lugar en que ellos puedan disfrutar, correr, les gusta mucho correr. Hay toda la línea de decanos lupus, los lobos, los chacales, los perros primitivos y después las subespecies, que el hombre hay ido cruzando, haciendo mutaciones. A mí me gusta mucho trabajar con el nórdico porque vendrían a ser la esencia, el principio de todo, todos los demás son razas que el hombre ha inventado (Hugo).

\footnotetext{
25 "Nature" was one of the terms used by the mushers to refer to dogs' aptitudes for the work - running and pulling a sled.

26 Alaskan Huskies, although not an "original” breed, result from a mixture of some of these "original” breeds. Alaskan Malamute, Siberian Husky, Pointer, Saluki and Anatolian Shepherd were the main breeds that initially made up the Alaskan Husky genetically (Huson et al. 2010:1).
} 
Figure 4. Photo sequence. Hernan and his dogs out for a ride. Criadero Siberianos de Fuego


Photos by the author, 2018

Hugo once told me: "así como los perros de trineo sienten la necesidad de correr y tirar, el border collie es un perro que siente la necesidad de agrupar, y es por eso que es un perro pastor tan bueno". For him and the other mushers, sled dogs are predisposed to run, and this is genetically explained. In this context, dogs learn to pull a sled in practice, but they only learn because running is one of their natural, instinctive and inherent characteristics:

El perro de trabajo se puede clasificar en distintas modalidades. Por ejemplo, un perro pastor. Un perro que es pastor es un perro de trabajo. Y un perro rescatista es un perro de trabajo. $Y$ un perro de búsqueda, de sobrevivientes, de explosivos, de droga, también es un perro de trabajo. El humano tiene un objetivo. $Y$ hasta que el perro tenga un año, tiene que haber una conexión entre el entrenador y ese perro para lograr este objetivo, y lo va seducir con premios [comida]. El perro vaquero [pastor] nace siendo vaquero. Le gusta juntar animales. Instintivamente nace com esa particularidad. Y el perro de trineo es un perro que también es un perro de trabajo, también tiene concebido dentro de su genética, su instinto ancestral, los aborígenes los concibieran para esto, para tirar (Hugo).

According to the above narrative, sled dogs have "inherent characteristics" that make them "natural pullers". However, what I would like to highlight here is the fact that these dogs are also defined, by the mushers, as "natural" working animals - as if they were, de facto, born to work. For the mushers, sled dogs are predisposed to run, and this is genetically explained. Although the dogs learn to pull in practice (between themselves and with the mushers), they are only capable of learning because running is one of their natural traits:

El trineo también remete los perros a su pasado, pero ellos pueden y les gusta mucho tirar otros objetos, cómo un esquí, una bici o un carro. El trineo es algo milenario, es especial, pero no es el objeto en sí, es la práctica, la acción de correr y tirar, que los encanta. Es su trabajo (Hernan). 
This was also pointed out by Kuhl (2011) in the Northern Hemisphere:

While it was not always stated explicitly in the interviews, it was clear that the dog's role in the partnership was to work/pull. This idea came through when participants explained that sled dogs are instinctually driven to run, love to pull, and are naturals at pulling from birth (Kuhl 2011:32).

Moreover, it is interesting to note that, for Hugo, when pulling a sled, dogs return to their "origins". This "origin" is an already domesticated origin, since it alludes to the first dogs that for millennia pulled sleds in the Arctic, dogs of the Inuit and Siberian peoples. For the mushers in Ushuaia, the origin of these dogs is sled pulling, to be working! It is curious that when they place sled dogs in an "ancestral past", they also place Inuit and Siberian peoples in that same "ancestral past" (erasing, in the same act, the history of these native groups from the North and the indigenous people in Tierra del Fuego). Furthermore, according to the mushers, the sled has this same effect on the "ancestral memory" of these animals; similar to the act of running and going "always forward", the sled itself also reports these dogs to this original, domesticated past. It's as if the dogs, in addition to being "born to work", were born knowing the sled:

El trineo hace parte de este pasado ancestral, porque era y aún es una herramienta de trabajo muy importante y presente en la vida de los pueblos originarios. A los perros les gusta tirar otras cosas también, como bicicletas y esquís, pero a ellos lo que más les gusta es correr, sin duda. Esto es el más importante. Pero vuelven a sus orígenes con los pueblos esquimos cuando tiran un trineo (Hugo).

It seems, then, that an "education for attention" and an "anti-education for attention" coexist in a single relationship. At the same time that they learn through practice, by doing, among themselves and with the mushers, the sled dogs are already "born" knowing how to pull a sled, as if this competence was natural to them. According to mushers' statements and practices, the dogs' abilities appear to be both innate and acquired. How can this ambiguity be understood? Hugo and the other mushers refer to the dogs' ability to pull a sled to their genetics, to their "nature"; and yet, deprived of sleds, these dogs would never develop this ability. How, then, could it be innate? I propose, as did Ingold (2000:366), that "the capabilities of action of both human beings and non-human animals are neither innate nor acquired but emergent properties of the total developmental system constituted by the presence of the agent (human or non-human) in its environment". Without a sled and without the practice - that is, outside the Criadero - would these dogs be draft animals? I do not think so.

Furthermore, something curious to think about: sled dogs, despite appearing to be more culture than nature, are not so considered by the mushers since they're "naturally" prone to running and pulling a sled. Indeed, these dogs seem to be naturally "made" to pull, since they've "emerged" pulling a sled. Unlike wild dogs, which have gone through a feralization process, the sled dogs are perfect natural-cultural hybrids, because it seems that at their origin nature and culture are not distinguished; they have emerged attached to the sleds. This kind of "origin myth" of these dog breeds is very interesting: the most "ancestral" seem to be the most adapted to an action designed by human beings. How do dogs manifest "ancestral" actions and how are they "genetically made"? The narratives in this context seem to combine nature and culture in a unique way: these dogs are simultaneously nature and culture, and the mushers apparently operate with this discursive ambiguity without realizing it, or without caring about it. Perhaps (and most likely), for them this ambiguity does not even exist. 
Relations of domestication are not necessarily unidirectional, nor do they follow rules (Cassidy \& Mullin 2007). In the context of Siberianos', dogs and mushers affect each other and are affected in their ongoing practices. Dogs have their bodies and behaviors continuously "perfected" through "selective pressures". However, we cannot simply ignore that mushers are also "made" in practice, from living with these dogs and sharing the same environment. The mushers, precisely because of the kind of relationship they cultivate day after day with the dogs, learn and develop certain skills, such as a "selective vision" at the expense of others, about which Grasseni (2005) wrote. Skills, according to Ingold (2000:360, original italics), "are developmentally incorporated into the modus operandi of the organism [human or non-human] through practice and experience in an environment". In that sense, among sled dogs and mushers the domestication relationship must be thought of as a process of mutual affectation (Swanson, Lien \& Ween 2018):

Domestication has a social and relational, but also technological and somatic impact on humans, which often is neglected but is, in fact, symptomatic of the fact that humans are just as much subject to the domesticatory interaction as animals and plants are (Stépanoff \& Vigne 2019:13).

Therefore, besides the "traditional narratives", that is, in a purely techno-economic approach (Stépanoff \& Vigne 2019), in our multispecific ethnographies we must start thinking about relations of domestication from a co-evolutionary perspective and as a continuous process:

"Domestication" refers to a becoming, a process set in time which causes living beings to go through different states, between the outside and the domus, between far and near, between predation and familiarity. Domestication does not simply cross these boundaries; it blurs them and questions categories, whilst at the same time adding its own apparent order by describing a succession of changes as oriented stages (Stépanoff \& Vigne 2019:3).

As Haraway (2003) suggested, it is from coexistence with companion species' that we must think about biopower, biosociality and technoscience in the world. Because of her close relationship with dogs and canine agility competitions, Haraway's reflections apply especially well to dogs and the relationships that we humans weave with them. But besides dogs, her arguments (Haraway 2003, 2008) address connections between species: above all, she is concerned about overcoming human exceptionalism and considering technology as a part of our relations with other humans and non-humans.

For mushing to succeed, a certain "operational harmony" is necessary between mushers, dogs and sleds. The challenge is always, according to Haraway (2008), to find coherence between incoherent worlds. And this harmony, in the context of this paper, is only achieved through coexistence and mutual observation and respect - that is, through the co-creation of a third language (Brandt 2004) and a human-canine participation in the process of co-domestication (Fijn 2011, 2018). As Fijn affirmed (2018:74), "human-canine relations involve different processes of development in both an ontological sense and an ontogenetic sense”.

\section{Final considerations: work as a domesticity regime}

Animal work, despite being a relatively debated topic in the humanities (Cf. Barreto 2015; Coulter 2016; Cummins 2009; Haraway 2003, 2008; Hobgood-Oster 2014; Losey, Wishart \& Loovers 2018; Morey 2010; Porcher 2014; Porcher \& Nicod 2019; Warren 2013), still needs further consideration: "diverse and complex realities of human-animal work relations remain relatively underexamined" (Coulter 2016:1). What do we know about working dogs (and working animals in general)? Moreover, Ingold (1980:88) has affirmed that "the domestic animal in the service of man constitutes labor itself rather than its instrument, and hence that the relationship between man and animal is in this case not a technical but a social one". 
I found it very interesting to reflect in this paper on the relations established between dogs (sled dogs, feral dogs and abandoned dogs) and humans (mushers, tourists and other inhabitants of Ushuaia) by considering animal work. It was from that category that I was able to unveil the fluidity of the different "statuses" and "becomings" of these dogs - or the different "products" of different material and semiotic relationships (or engagements) - in Tierra del Fuego, as well as the ambiguities of what, for these humans, would be natures and cultures, wild and domesticated:

By recognizing the nature-labor nexus and animal work, we are encouraged to think about entire species and individual animals. We recognize but move beyond boundaries like "wild" and "domesticated", and "the environment" versus "animals", in favor of a more integrated approach. By using animal work as a conceptual engine, we also complicate other binaries like "urban" and "rural", as humans and animals live, work, move, are moved, and are killed across spaces in a more fluid dynamic (Coulter 2016:12).

It is very curious, for instance, that mushers affirm that the sled dogs' natural "vocation" for work - which, as Marx stated, is social and therefore human - is the result of these dogs' genetic inheritance from wolves and their "ancestral" canine genes, in addition to genetic manipulation. While on the other hand, while defining mushing as the exploitation of animals, tourists do not hesitate to pay for the tour. It's a constant interplay of categories, and it seems that mushers, tourists and Fuegians do not perceive the ambiguities of the conceptual combinations they use in their reflections. Perhaps "this is because the dog is perceived as being neither fully of nature (being a domestic animal) nor of culture (being essentially a wolf, sharing that species' DNA)" (Cummins 2009:99).

Figure 5. Leonardo and his dogs arriving from a ride. Criadero Siberianos de Fuego



Photo by the author, 2018 
Work, in this context, seems to operate as a domesticity regime. Piero Leirner, in an unpublished manuscript, suggested that "the consumption of the animal labor force (...) is as productive as that of the human labor force". Furthermore, for Leirner "oxen came out of the condition known as 'wild pets' precisely because they pledged as a condition of their domestication their engagement in the form of (...) producers of their own conditions of production". It seems to me that sled dogs in Siberianos are also producers of their own production conditions: without them, there would be no economic touristic practice of mushing in Ushuaia. As parts of the same production system, dogs and mushers work, live together and cohabit the same environment. Tourism work itself is, at least in part, an alternative for those (humans) interested in this kind of relationship. As Porcher suggested in relation to other contexts, I propose that the main gain (in a pecuniary sense) from this economic practice in Tierra del Fuego serves, perhaps mainly, to preserve this very particular cohabitation of dogs and mushers: "Living together is a founding rationale of work. (...) Animals do not serve just to generate income; it is income that serves cohabitation with livestock" (Porcher 2014:4).

On the other hand, there are animals that are outside the realm of humans - and therefore beyond the power relationships and structures that would give them any degree of significance. Here I am thinking exclusively about dogs and their different statuses. In Tierra del Fuego, it's the so-called wild dogs that best reflect this condition. As far as they are concerned, these animals left their condition of "domestic animal" precisely because they lost their condition as "work producer" - either pulling sleds or working "informally" (Coulter 2016:77) in Fuegian homes as pets. And yet, despite occupying a position as an invasive alien species, "the feral is the element that makes every set or regime of domesticity an unconscious totality, a structure that is necessarily hollow and porous, permeated by multiple lines of escape" (Sordi 2017:288).

In turn, dogs on Ushuaia's streets are located in transitory categories, between those who have owners and those who live in "jaurías" and attack Fuegian sheep flocks - the feral dogs par excellence: "perros callejeros" may be abandoned dogs, "runaway" dogs, and even dogs deliberately released by their owners for a short (or long) period. Yet, as among animal protectors with whom Osório worked, in Ushuaia "the domestication process only makes sense if the animal becomes property" (Osório 2013:157) - or may become, as is the case with stray dogs. For those who have already lost their status as "domestic animal", "wild" and "feral" are the most common adjectives.

On the one hand, feral dogs have become feral as a result of abandonment; they therefore owe their "nature" to a "cultural" practice. On the other hand, sled dogs are, according to the mushers, "naturally" good workers. Meanwhile, for tourists, they're either "poor things" who shouldn't work (because dogs are pets, not workers!) or they arouse interest and fascination for being very similar to wolves - in other words, for being (almost) wild. Maybe they arouse interest precisely because of their condition as "almost wild", because they represent, in a certain way, the domestication of the wild (through work). About the Patou (a herding canine breed), Cummins wrote that "while domesticated, the Patou reminds us of the wild" (Cummins 2009:120). In a sense, it's as if the very idea of work - and in the case of wild dogs, of feral - was intuitive, independent of experience and practice, as if it originally had nothing to do with humans.

It was from this abundance of canines - and the fluidity of these animals' statuses - that I was able to reflect in this paper on the existence of a spectrum that ranges from domestic to wild, passing through interstitial categories. Among the Fuegian dogs, the domestic/wild and nature/culture dichotomies tend to be more inter-related than separated domains. As Vander Velden suggested (2018:43), recognizing "the richness and porosity of the boundaries between nature (wild/sylvan) and culture (domestic/domesticated)" leads us, for example, "to rethink domestication as a continuous and permanent process". 
There has been much discussion in anthropology about dogs as pets (Oliveira 2006; Segata 2012; Pastori 2012; Teixeira 2016), while largely ignoring dogs in other contexts - including work, sport, the market and their condition as feral animals, themes that are dear to this paper. This has limited our understanding of what a dog is and what a dog can do and the relations that connect them to human collectives, since there are different ways of being with dogs (Fijn 2018) and different ways of being a dog. Thus, throughout this paper the relationships between dogs, sleds and humans, as well as between feral dogs, humans and other non-humans, were thought of as naturecultures (Haraway 2003, 2008), which are connected through work (and the absence of work), in an attempt to reveal what dogs can do and what they are in Tierra del Fuego.

Received: September 12, 2019

Approved: January 22, 2020

Translation by the author

Revised by Jeffrey Hoff

\section{References}

BARRETO, Eric Silveira. 2015. Por dez vacas com cria eu não troco meu cachorro: as relações entre humanos e cães nas atividades pastoris do pampa brasileiro. Dissertação de Mestrado, Universidade Federal de Pelotas Pelotas.

BRANDT, Keri. 2004. "A language of their own: an interactionist approach to human-horse communication”. Society \& Animals, 12(4): 299-316.

CASSIDY, Rebecca; MULLIN, Molly. 2007. "Introduction: domestication reconsidered". In: R. Cassidy \& M. Mullin (eds.), Where the wild things are now: domestication reconsidered. New York: Berg. pp. 1-25.

COPPINGER, Raymond; SCHNEIDER, Richard. 2017. "Evolution of working dogs”. In: J. Serpell (ed.), The domestic dog: its evolution, behavior and interactions with people. Cambridge: Cambridge University Press. pp. 21-47.

COULTER, Kendra. 2016. Animals, work, and the promise of interspecies solidarity. Basingstoke: Palgrave Macmillan.

CROSBY, Alfred. 2011. Imperialismo ecológico: a expansão biológica da Europa, 900-1900. São Paulo: Companhia das Letras.

CUMMINS, Bryan. 2009. Bear Country: predation, politics, and the changing face of Pyrenean Pastoralism. Durham: Carolina Academic Press.

DIGARD, Jean-Pierre. 2012. "A biodiversidade doméstica, uma dimensão desconhecida da biodiversidade animal”. Anuário Antropológico, 37(2): 205-223. 
FIJN, Natasha. 2011. Living with herds: human-animal coexistence in Mongolia. New York: Cambridge University Press.

. 2018. "Dogs ears and tails: different relational ways of being with canines in aboriginal Australia and Mongolia". In: H. A. Swanson; M. E. Lien \& G. B. Ween (eds.), Domestication gone wild: politics and practices of multispecies relations. Durham: Duke University Press. pp. 72-93.

FOGLE, Bruce. 2009. Guia Ilustrado Zahar: cães. Rio de Janeiro: Zahar.

GRASSENI, Cristina. 2005. "Disciplining vision in animal biotechnology". Anthropology in Action, 12(2): 44-55.

HARAWAY, Donna J. 2003. The companion species manifesto: dogs, people, and significant otherness. Chicago: Prickly Paradigm Press. . 2008. When species meet. Minneapolis: University of Minnesota Press.

HOBGOOD-OSTER, Laura. 2014. A dog's history of the world: canines and the domestication of humans. Waco: Baylor University Press.

HUSON, Heather J. et al. 2010. "A genetic dissection of breed composition and performance enhancement in the Alaskan sled dog". BMC Genetics, 11(1): 71.

INGOLD, Tim. 1980. Hunters, pastoralists and ranchers: Reindeer economies and their transformations. Cambridge: Cambridge University Press. 200o. The perception of the environment: essays in Livelihood, Dwelling and Skill. London: Routledge.

KOHN, Eduardo. 2013. How forests think: toward an anthropology beyond the human. Berkeley: University of California Press.

KUHL, Gail. 2011. "Human-sled dog relations: what can we learn from the stories and experiences of mushers?". Society \& Animals, 19: 22-37.

LEACH, Helen. 2007. "Selection and the unforeseen consequences of domestication”. In: R. Cassidy \& M. Mullin (eds.), Where the wild things are now: domestication reconsidered. New York: Berg. pp. 71-99.

LEAL, Natacha. 2018. "Dos manuais que fazem raça: técnicas e enunciados sobre purezas zootécnicas". R@U, $10(1): 25-52$.

LIEN, Marianne Elisabeth; LAW, John. 2011. “Emergent Aliens': On Salmon, Nature, and Their Enactment”. Ethnos, 76(1): 65-87.

LOSEY, Robert J.; WISHART, Robert P. \& LOOVERS, Jan Peter Laurens (eds.). 2018. Dogs in the North: stories of cooperation and co-domestication. New York: Routledge.

MOREY, Darcy. 2010. Dogs: domestication and the development of a social bond. Cambridge: Cambridge University Press.

OLIVEIRA, Samantha B. C. 2006. Sobre homens e cães: um estudo antropológico sobre afetividade, consumo e distinção. Dissertação de Mestrado, Universidade Federal do Rio de Janeiro - Rio de Janeiro.

OSÓRIO, Andréa. 2013. “A cidade e os animais: da modernização à posse responsável”. Teoria \& Sociedade, 21(1): 143-176.

PASTORI, Érica Onzi. 2012. Perto e longe do coração selvagem: um estudo antropológico sobre animais de estimação em Porto Alegre, Rio Grande do Sul. Dissertação de Mestrado, Universidade Federal do Rio Grande do Sul Porto Alegre.

PORCHER, Jocelyne. 2014. “The work of animals: a challenge for Social Sciences”. Humanimalia: A Journal of Human-Animal Interface Studies, 6(1): 1-9.

.; NICOD, Sophie. 2019. “Domestication and animal labour”. In: C. Stépanoff; J. Vigne (eds.), Hybrid communities: biosocial approaches to domestication and other trans-species relationships. New York: Routledge. pp. 251-259. 
SANTOS, Bruno Silva. 2018. "Dó e alegria: relações entre os Guarani-Mbya e seus cães no Jaraguá/SP”. Ambivalências, 5: 49-81.

SAUTCHUK, Carlos Emanuel; STOECKLI, Pedro. 2012. "O que é um humano? Variações da noção de domesticação em Tim Ingold”. Anuário Antropológico [Online] II: 227-246. Available in <http:/|aa.revues. org/238>. Accessed August 12, 2019.

SCHIAVINI, Adrián; NARBAIZA, Carla. 2015. Conflictos derivados de las poblaciones caninas en Tierra del Fuego. Informe realizado por solicitud del Comité de Emergencia Agroganadero y de Alerta Sanitaria de Tierra del Fuego. Available in < https:/|www.researchgate.net/publication/277021246_Conflictos_derivados_de_ las_poblaciones_caninas_en_Tierra_del_Fuego>. Accessed August 15, 2019.

SEGATA, Jean. 2012. Nós e os outros humanos, os animais de estimação. Tese de doutorado, Universidade Federal de Santa Catarina - Florianópolis.

SIGAUT, François. 2007. “Le labour, qu'est-ce que c'est?”. In : R. Bourrigaud \& F. Sigaut (dirs.), Nous labourons. Actes du colloque Techniques de travail de la terre, hier et aujourd'hui, ici et là-bas. Nantes: Centre d'Histoire du Travail. pp. 21-27.

SORDI, Caetano. 2017. Presenças ferais: invasão biológica, javalis asselvajados (Sus scrofa) e seus contextos no Brasil Meridional em perspectiva antropológica. Tese de doutorado, Universidade Federal do Rio Grande do Sul Porto Alegre.

STÉPANOFF, Charles; VIGNE, Jean-Denis. 2019. "Introduction”. In: C. Stépanoff \& J. Vigne (eds.), Hybrid communities: biosocial approaches to domestication and other trans-species relationships. New York: Routledge. pp. 1-20.

SWANSON, Heather Anne; LIEN, Marianne Elisabeth; WEEN, Gro B. 2018. "Introduction: naming the Beast - exploring the Otherwise”. In: H. A. Swanson; M. E. Lien \& G. B. Ween (eds.), Domestication gone wild: politics and practices of multispecies relations. Durham: Duke University Press. pp. 1-30.

TEIXEIRA, Ivana. 2016. "A relação entre homens e animais no mundo da cinofilia: uma análise antropológica”. In: C. Bevilaqua \& F. Vander Velden (orgs.), Parentes, vítimas, sujeitos: perspectivas antropológicas sobre relações entre humanos e animais. Curitiba: Ed. UFPR; São Carlos: EdUFSCar. pp. 103-117.

TSING, Anna. 2012. “Unruly edges: mushrooms as companion species”. Environmental Humanities, 1(2012): 141-154.

VANDER VELDEN, Felipe Ferreira. 2012. Inquietas companhias: sobre os animais de criação entre os Karitiana. São Paulo: Alameda. . 2016. "Como se faz um cachorro caçador entre os Karitiana (Rondônia)". Teoria e Cultura, 11(2): 25-35. . 2018. Joias da floresta: antropologia do tráfico de animais. São Carlos: EdUFSCar.

VATIN, François. 2019. O trabalho e suas medidas: economia, física e sociedade. Campinas: Mercado de Letras. WARREN, Cat. 2013. What the dog knows: the science and wonder of working dogs. New York: Simon \& Schuster.

Luisa Amador Fanaro

Federal University of São Carlos

Social Anthropology Postgraduate Program, São Carlos/SP, Brazil

https://orcid.org/oooo-0001-6249-5481

Email: luisafanaro@hotmail.com 